\title{
Factors affecting online impulse buying on social commerce in Indonesia: The moderation role of perceived financial risk
}

\author{
V.P. Cecianti \& S.R. Hijrah Hati \\ Faculty of Economics and Business, Universitas Indonesia, Indonesia
}

\begin{abstract}
In recent years, social commerce, which combines social and commercial activities, has been considered as a great innovation, one that has been particularly useful during the COVID19 pandemic, which has affected various sectors. Many social commerce platforms have updated their features to facilitate commercial transaction. Indonesian consumers tend to exhibit impulse buying behavior that is affected by situational factors, such as interpersonal influence, information fit-to-task, visual appeal, portability, and time pressure. This study sought to analyze factors and motivations that influenced online impulse buying. The results indicate that the situational factors differently affected hedonic motivation and utilitarian motivation. Hedonic motivation directly and positively influenced impulse buying. This study also argues that financial risk influenced online impulse buying and mitigated perceived value's role as a motivator.
\end{abstract}

\section{INTRODUCTION}

Recently, social media has not only been used for social interaction and communication but has also been used in the business sector, so that everyone can meet their needs and support their business. Han and Kim (2016) affirm that social media currently has increasing business activities, which is known as social commerce. In recent years, social commerce, which combines social and commercial activities, has been considered as a great innovation, and it has been useful during the COVID-19 pandemic, which has affected various sectors around the world (Siagian, 2020). However, this activity has a weakness in terms of insecurity when transacting on social media due to the lack of capacity for payments in joint accounts, such as in e-commerce. Therefore, the risk of financial loss certainly makes consumers be more careful to do online shopping on social commerce.

During this pandemic, consumer behavior has shifted significantly to online buying and impulse buying. Moreover, these motivations can be the underlying consumer behavior, and they also have encouraged people to engage in certain behaviors (Kim et al., 2007). This study argues that perceived financial risk plays a role in moderating the influence of motivations on online impulse buying. Also, in practice, online retailers need to know the situational factors, such as interpersonal influence, information fit-to-ask, visual appeal, portability, and time pressure, which significantly influence people to make online impulse buying. This study seeks to find out the most important situational factors that influence the online impulsive buying process.

\section{LITERATURE REVIEW}

According to Solomon and Rabolt (2009), impulse buying is an individual condition in making a purchase that is influenced by feelings of urgency and difficulty to refuse or postpone. This study adopts urge to buy to measure individuals' impulsivity because it is problematic to observe the actual behavior in a controlled environment (Luo, 2005). The impulsive buying process is motivated by several behaviors, namely, hedonic motivation and utilitarian motivation. A hedonic motivation is 
the willingness to initiate pleasurable or favorable behavior in order to reduce negative experiences (Kaczmarek, 2017), while a utilitarian motivation is a consumer behavior based on objective and rational values (Hanzaee et al., 2011). Both hedonic and utilitarian motivations have encouraged people to engage in certain behaviors, such as shopping (Kim et al., 2007). The consumer feels or pays attention to the stimulus, assimilates it, and then reacts to do impulse buying. According to Piron (1991), the stimulus (situation factor) can be in the form of an actual product, a shopping environment, or a person accompanying shopping.

In this study, impulse buying on social commerce is affected by the situational factors, namely, interpersonal influences, information fit-to-task, visual appeal, portability, and time pressure. According to Lee and Kacen (2008), interpersonal influence is important for individuals' buying behavior, especially in collectivist countries. Information fit-to-task is linked to the quality of information from a product on a particular site, such as accuracy, reliability, completeness, timeliness, and relevance of the information (Peter and McLean, 2009). Visual attractiveness relates to the user interface of a website which initially attracts the users' attention. Varela et al. (2013) state that the visual attractiveness of a website refers to the level of consumer confidence in the pleasing appearance of the site that stimulates the desire to browse. Portability is important, especially for people with high mobility; the longer the time spent browsing, the more is the contact with various stimuli and the more likely it is to induce the user's hedonic and utilitarian motivation. Consumers who usually have time pressure tend to think less carefully when making purchases (Howard and Sheth, 1969). Social commerce does not provide financial transactions directly integrated with the system, such as e-commerce; payment methods on social commerce for consumers are confusing and difficult. Biswas and Biswas (2004) revealed that the high financial risk to online purchases is caused by conditions in which buyers cannot directly contact the seller, so they perceive that the seller lacks credibility.

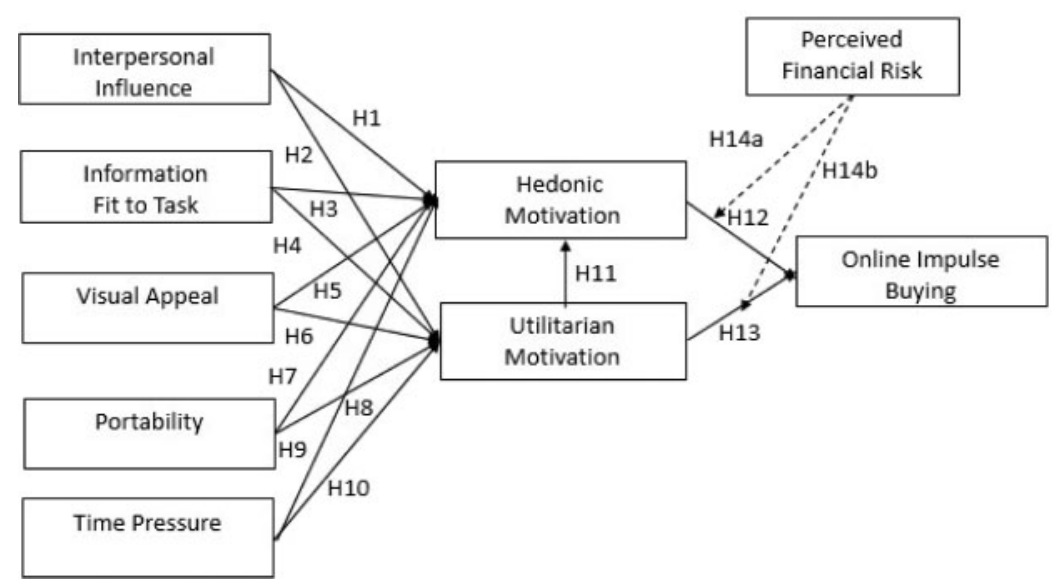

Figure 1. Conceptual framework.

\section{RESEARCH METHODS}

This study employs a quantitative approach using a survey method through online questionnaires with the Likert scale $1-5(1=$ strongly disagree; $5=$ strongly agree $)$. This study was conducted in Indonesia by using a purposive sampling technique that determined the respondents' characteristics, namely, Indonesian consumers who are over 17 years old and have been exposed to social commerce on the most popular social media, such as Instagram, Facebook, WhatsApp, Twitter, and TikTok, in the last 6 months. Based on the data collection, 331 respondents filled out the survey with 326 valid responses obtained for the final data analysis. 


\section{DATA ANALYSIS AND RESULTS}

This study used Lisrel 8.54, and the data were then processed using the structural equation model (SEM) to analyze and evaluate the measurements and structural models of this study. Based on confirmatory factor analysis, all indicators and variables were valid and reliable (SLF $\geq 0.50$; t-value $\geq 1.645 ; C R \geq 0.70 ; \mathrm{VE} \geq 0.50$ ). This study had a good fit model with good absolute fit, incremental fit, and parsimony fit indices. Based on 15 hypotheses, eight hypotheses were supported, including H1 $(\mathrm{t}=2.47), \mathrm{H} 4(\mathrm{t}=2.77), \mathrm{H} 5(\mathrm{t}=2.62), \mathrm{H} 8(\mathrm{t}=5.07), \mathrm{H} 9(\mathrm{t}=3.08), \mathrm{H} 11$ $(\mathrm{t}=2.67), \mathrm{H} 12(\mathrm{t}=7.05)$, and $\mathrm{H} 14 \mathrm{~b}(\mathrm{t}=-2.72)$. The result of the structural model is presented in Table 1.

Table 1. Path diagram results for the structural model.

\begin{tabular}{llrlrlrl}
\hline $\mathrm{H}$ & Path & T-value & Evaluation & \multicolumn{1}{c}{$\mathrm{H}$} & Path & T-value & Evaluation \\
\hline 1 & IF-HD & 2.47 & Supported & 9 & TP-HD & 3.08 & Supported \\
2 & IF-UT & -0.27 & Not Supported & 10 & TP-UT & 1.15 & Not Supported \\
3 & IFT-HD & 1.03 & Not Supported & 11 & UT-HD & 2.67 & Supported \\
4 & IFT-UT & 2.77 & Supported & 12 & HD-IB & 7.05 & Supported \\
5 & VA-HD & 2.62 & Supported & 13 & UT-IB & 0.25 & Not Supported \\
6 & VA-UT & 1.27 & Not Supported & 14 & FR (HD-IB) & 6.36 & Not Supported \\
7 & PRT-HD & 0.07 & Not Supported & 15 & FR (UT-IB) & -2.72 & Supported \\
8 & PRT-UT & 5.07 & Supported & & & & \\
\hline
\end{tabular}

Hedonic and utilitarian motivations underlie the situational factors that influence impulse buying in this study. In line with Xiang et al. (2016), information fit-to-task and portability were variables that affected utilitarian motivation. In other words, when more information is available, consumers will likely assume that the shopping platforms are useful and also portability will increase the utilitarian value in making portability purchases. Also, interpersonal influence in social commerce had a significant effect on consumer hedonic motivation. This result was in line with the research conducted by Arnold and Reynolds (2003), who reported on where and who people seek advice from when they are going to shop. Time pressure in social commerce had a significant effect on consumer hedonic motivation but an insignificant effect on consumer utilitarian motivation. Chang and Chen (2015) consider that time pressure has a negative impact, especially on utilitarian motivation. Time pressure will limit individuals to consider all the information needed when making decisions and lead them to make irrational decisions. Furthermore, a visual appeal had a significant effect on consumer hedonic motivation. This result is in line with Tractinsky et al. (2000), who illustrated that a website interface will affect the first impression and help the user to evaluate.

In comparison to utilitarian motivation, hedonic motivation had a strong and positive effect on the consumers' impulse buying. This is supported by Zheng et al. (2019), who identified hedonic motivation as the main determinant of consumer purchasing behavior (Kukar-Kinnery \& Close, 2010). Utilitarian motivation had an insignificant effect on impulse buying but had an indirect influence on online impulse buying by affecting hedonic motivation. This result is in accordance with the research conducted by Babin et al. (2004), who stated that the utilitarian value is expected to complement hedonic values and not to be a contrasting value. The moderation test shows that perceived financial risk did weaken the relationship between consumers' utilitarian value. This condition reduced the desire to make an unplanned online buying. This is consistent with the research conducted by Biswas and Biswas (2004), who revealed that the high financial risk to online purchases is caused by conditions in which buyers cannot directly contact the seller, so they perceive the seller to lack credibility. Consumers will rethink and be more careful in online shopping. However, the perceived financial risk did not weaken the relationship between consumers' hedonic value because consumers had experiences in purchasing products from social commerce (Chang \& Tseng, 2010) and need to experience varied, novel, and complex sensations (Zuckerman, 1979). 


\section{CONCLUSION AND SUGGESTIONS}

This study shows how the situation factors, such as interpersonal influences, information fit-totask, visual appeal, portability, and time pressure induced consumers' impulse buying behavior in social commerce in Indonesia. In addition, it revealed interesting findings in the social commerce that hedonic motivation was the most underlying situational factor that influenced impulse buying compared to utilitarian motivation, which had an indirect influence on online impulse buying by affecting hedonic motivation. Thus, social commerce retailers need to design more attractive interfaces in order to encourage consumers to browse and buy or make a good marketing strategy based on hedonic value, and social commerce needs to provide good quality information and the mobility of their market target. The moderation test shows that perceived financial risk did weaken the relationship of consumers' utilitarian value. Therefore, online retailers may provide mechanisms for secure payment and after-sale evaluations to reduce customers' perceived risk.

\section{REFERENCES}

Arnold, M.J. and Reynolds, K.E. 2003. "Hedonic shopping motivations", Journal of Retailing,Vol. 79, pp. 77-95.

Babin, B. J., Chebat, J. C., \& Michon, R. 2004. Perceived appropriateness and its effecton quality, affect and behavior. Journal of Retailing and Consumer Services, 11(5),287-298

Biswas, D., Biswas, A. and Das, N. 2006, "The differential effects of celebrity and expertendorsements on consumer risk perceptions", Journal of Advertising, Vol. 35 No. 2,pp. 17-31

Chang, C. C., \& Chen, C. W. 2015. Examining hedonic and utilitarian bidding motivations in online auctions: Impacts of time pressure and competition. Internal Journal of Electronic Commerce, 19(2), 39e65.

Close, A. G., \& Kukar-Kinney, M. 2009. Beyond buying: Motivations behindconsumers' online shopping cart use. Journal of Business Research, 63(9-10),986-992.

Han, M. C., \& Kim, Y. (2016). Can Social Networking Sites Be E-commerce Platforms? Pan-Pacific Journal of Business Research, 7(1), 24.

Hanzaee, K. H., \& Khonsari, Y. 2011. A Review of The Role of Hedonic and Utilitarian Values on Customer's Satisfaction and Behavioral Intentions.Interdisciplinary Journal of Research in Business, Vol. 1, Issue. 5, May (pp.34-45).

Howard, J. A. and Sheth, J. N. 1969. "The theory of buyer behavior," John Wiley and Sons, Inc.

Kaczmarek,Lukasz D. 2017. Hedonic Motivation. Poland :Springer International Publishing

Lee, J. \& Kacen, J.J. 2008. Cultural influences on consumer satisfaction with impulse and planned purchase decisions, Journal of Business Research 61(3), pp.265-272.

Luo, X. 2005. How does shopping with others influence impulsive purchasing? Journal of Consumer Psychology, 15(4), 288-294.

Petter, S. \& Mclean, E.R., 2009. A Meta-Analytic Assessment of Delone and Mclean IS Success Model: An Examination of IS Success At The Individual Level. Elsevier, 46(3), pp. 159-166

Varela, M., Maki, T., Kapov, L., \& Hobfel. T. 2013. Toward an Understanding of Visual Appeal in Website Design. COST QUALINET Action IC1003

Park, E.J., Kim, E.Y., Funches, V.M. and Foxx, W. 2012, "Apparel product attributes, webbrowsing, and e-impulse buying on shopping websites", Journal of Business Research,Vol. 65, pp. 1583-1589 Piron, F. (1991). Defining impulse purchasing.ACR North American Advances, 18,509-514.

Solomon, M.R. \& Rabolt, N. 2009. Consumer Behaviour in Fashion, 2nd. Edition. USA: Prentice Hall

Tractinsky, N., Katz, A.S., \& Ikar, D. 2000. What is beautiful is usable. Interacting with Computers, 13, $127-145$

Xiang. L., Zheng. X., Lee. M.K.O.,Zhao.D.2016. Exploring Consumers' Impulse Buying Behavior on Social Commerce Platform: The Role of Parasocial Interaction. International Journal of Information Management $36,333-347$

Zheng. X., Men. J., Yang. F., Gong. X. (2019) Understanding Impulse Buying in Mobile Commerce: An investigation into hedonic and utilitarian browsing. International Journal of Information Management 48, 351-160.

Zuckerman, M. .1979.Sensation Seeking: Beyond the Optimal Level of Arousal. Lawrence Erlbaum Associates, Hillsdale, NJ, USA. 